and teachers in the United States who use infra-red spectroscopy. The Society has been given its name in honour of William W. Coblentz, retired chief of the Radiometry Section of the National Bureau of Standards, Washington, D.C., and pioneer in infrared spectroscopy. It is not intendod that the Society should compete with the existing formal organizations for the analytical and physical chemists, physicists, military specialists and such-like; but rather it will cut across the boundaries that separate the various disciplines so as to provide an informal mechanism by which the people who use infra-red can take joint efforts on common problems. At the Ohio State conference on molecular structure and spectroscopy, held in Columbus last June, Dr. Norman Wright, of the Dow Chemical Co., Midland, Michigan, was appointed chairman of the new Society by the executive board of the Committee on Infrared Spectroscopy. Those interested in joining the Coblentz Society should write to the registrar, Dr. V. Z. Williams, c/o The Perkin-Elmer Corporation, Norwalk, Conn.

\section{United States Committee on Loyalty Requirements in Unclassified Research}

IN connexion with the recent request by the United States Administration that the National Academy of Sciences should advise the Federal Government on its policy in dealing with relations between questions of loyalty and the awarding of Government grants and contracts in support of unclassified research, a committee has been formed with the following members: J. A. Stratton, vicepresident and provost of the Massachusetts Institute of Technology (chairman); Robert F. Bacher, chairman of the Division of Physics, Mathematics and Astronomy, California Institute of Technology; Laird Bell, a lawyer who until recently was chairman of the Board of Trustees of the University of Chicago ; Wallace O. Fenn, assistant dean of the School of Medicine and Dentistry, University of Rochester; Robert F. Loeb, director of medical service, New York Presbyterian Hospital and trustee of the Rockefeller Foundation; E. Bright Wilson, jun., Richards professor of chemistry, Harvard University ; and Henry M. Wriston, president of Brown University.

\section{Specific Gravity of Alcoholic Spirits at $20^{\circ} \mathrm{C}$.}

UNDER the authority of the Commissioners of Customs and Excise, tables have been prepared showing the relation between the specific gravity of spirits at ${ }_{20}^{20} \mathrm{C} .\left(68^{\circ} \mathrm{F}\right.$.) and the percentage of ethyl alcohol by weight and by volume, with the corresponding percentage of proof spirit (pp. 35. London: H.M.S.O., 1954 ; 4s. net). The tables have been compiled by Mr. A. F. Weiss, of the Government Chemist's Department, Liverpool, and are based on data from existing tables at $60^{\circ} \mathrm{F}$., issued by the Commissioners in 1916, together with the values for the thermal expansion of ethyl alcohol given by the United States Bureau of Standards (Bull., 9, 424; 1913). The choice of $20^{\circ} \mathrm{C}$. has been made because this temperature is now commonly accepted as a standard in analytical work; it is emphasized in the preface to the tables, however, that they merely supplement and do not supersede the "Official Spirit Tables" based on $60^{\circ}$ and $80^{\circ} \mathrm{F}$. The new publication contains four tables, the first of which relates the specific gravity in air at $20^{\circ} \mathrm{C}$. (relative to water at $20^{\circ} \mathrm{C}$. as unity) to the percentage of proof spirit and the percentages of alcohol by weight and by volume; the range $100-0$ per cent is covered in 2,100 steps. The other three tables refer to dilutions by volume of two, three and four times, respectively; each contains three columns showing the specific gravity after dilution, the corresponding proof strength before dilution and the percentage of alcohol by volume before dilution.

\section{Storage Equipment and Methods in Libraries}

A HANDBOoK on "Modern Storage Equipment and Methods for Special Materials in Libraries" (pp. 32 ; $1955 ; 2 s .6 d$.$) has been issued in connexion with an$ exhibition of such equipment and methods held in the Council Chamber of the Library Association during January 11-12. It has been prepared by R. L. Collison, from whom it is obtainable (at $7 a$ Worsley Road, London, N.W.3), and contains a foreword by J. H. Davies. It includes notes on the handling of different types of material, including atlases, films, film strips, gramophone records, lantern slides, maps, microfilms, news clippings, newspapers and pamphlets, arranged alphabetically; there is also information useful to the research worker who has collected such materials, as well as to the librarian. Besides references under the particular headings, the handbook contains a general bibliography and a directory of advertisers and suppliers of the equipment recommended.

\section{Paper Chromatography of Plant Viruses}

Relatively little has been done on paper chromatographic methods for the identification and isolation of viruses. H. W. J. Ragetli and J. P. H. Van Der Want (Proc. Koninkl. Nederlandse Akad. Wetens., 57, No. 5, Ser. C. 621 ; 1954) have now reported in some detail on methods they have found useful for the chromatography of tomato mosaic virus on filter-paper strips with water, various concentrations of sodium chloride, acetate-acetic acid buffer solutions, and an acetone-water mixture, respectively, as solvents. Attempts to identify the presence of tomato mosaic virus with a spot that strongly absorbed ultra-violet of about $265 \mathrm{~m} \mu$ wave-length in the chromatograms were unsuccessful. It has thus far been possible to locate the virus only by inoculating Nicotiana glutinosa with extracts prepared from zones cut from the paper strips. The method is considered to be promising as a simple test for the estimation of certain impurities in purified virus preparations and for the preparation of viruses for electron microscopy from low-speed centrifuged sap of diseased plants.

\section{Diatom Flora of Sweden and Finland}

THE fourth part of the extensive diatom flora "Die Diatomeen von Schweden und Finnland" (in German), by Astrid Cleve-Euler (Kungl. Svenska Vetenskapsakademiens Handlingar, 5, No. 4, 1955 ; Stockholm. $62 \mathrm{Kr}$.$) , relates to the Biraphideae, that is, organisms$ of the affinity of species such as Navicula, Pinnularia, Cymbella, etc., both living and fossil species being described and illustrated, and localities enumerated. The work is essentially taxonomic in its aims and presentation, and contains no general discussion.

\section{Guinier-type X-ray Camera}

A ReCENT Harwell report by R. W. M. D'Eye (A.E.R.E. $C / R$ 1524, available from H.M.S.O., London) describes the construction of a Guinier-type 